\title{
Design of Genre Based Learning Model Integrated in Literacy Activities and Character Strengthening for Middle School Students
}

\author{
Atmazaki $^{1}$, Agustina ${ }^{2}$, Abdurahman $^{3}$, Vivi Indriyani ${ }^{4}$ \\ \{atmazaki@fbs.unp.ac.id ${ }^{1}$, tien_agustina08@yahoo.com ${ }^{2}$, abdurahman.padang@gmail.com ${ }^{3}$, \\ vivi.indriyani93@gmail.com $\left.{ }^{4}\right\}$ \\ 1,2,3 Universitas Negeri Padang, Indonesia
}

\begin{abstract}
Government policies regarding education continue to experience innovation to improve education. The policies are like curriculum changes, school literacy movements, and strengthening student character. However, integrating this into the learning process is not easy. Therefore, learning innovations are needed to overcome this. One of them is the development of learning models. The purpose of this study was to develop a genre based learning model design that integrated literacy activities and character strengthening for middle school students. This type of research is research and development. The learning model development process is carried out following the Plomp model (preminary research, prototyping phase, and assessment phase). The results of this study produce a prototype of a learning model consisting of build context, explore genres, building field knowledge, report reading, analyzing genre, constructing individual texts/groups, evaluation, presentation and reflection. The learning model that is designed in the category is very valid and can then be tested.
\end{abstract}

Keywords: genre based learning, literacy activities, character strengthening

\section{Introduction}

Genre-based approaches have proven successful in teaching languages at the school level to the university level [1][2]. It can be seen from this approach that it has been widely adopted in language teaching and research [3][4][5]. Many researchers have tried to improve, adapt, or integrate teaching theory in accordance with this teaching technique by developing learning models or methods [6][7][8][9][10][11]. Based on some of the results of these studies indicate that this approach has been developed, especially in the learning syntax [6][7][9]. For example, a genre-based approach was developed by creating a genre-based learning model consisting of three stages of learning developed by adding two stages of learning as a starting and ending step for reading learning [10]. In addition, other studies develop a genre approach and a process approach together as alternatives in a model called "process-genre approach" to improve student literacy skills [12].

Genre-based Learning is basically supported on different principles from the main pillar of which is text [13]. Related to this, in the education curriculum in Indonesia, Indonesian language learning uses a text-based curriculum, which applies the steps of language learning by using the Genre-based Learning model as a basis for learning [14]. A genre-based approach or a text-based approach is a communicative language teaching trend that looks at 
communicative competence by involving the mastery of various types of texts in a particular context [7]. This learning aims to improve communicative competence through various types of oral and written texts, including the exchange of conversations and discussions on complicated topics and described in informational texts, story texts, and persuasive texts [6].

The most targeted skills to be improved in language learning by using Genre-based Learning are reading and writing [6][11][15][16][17]. Applying Genre-based Learning in teaching reading and writing can lead to rapidly increasing skills outcomes [16][18]. In addition to improving student literacy skills, Genre-based Learning can bring about positive writing attitudes that have an impact on the acquisition of knowledge and awareness of genre conventions to help increase students' confidence in language learning [18][19]. In addition, Genre-based Learning is useful for raising awareness [20][21], increasing academic literacy [9], increasing motivation to comprehend texts analytically, encouraging more critical thinking [10], developing student self efficacy [17]; and increasing communicative competence [22].

Literacy has not become a culture in school life. Some things that can be the cause of this are as follows. First, students tend to only read when at school, reading activities at home are done if there are assignments given [23]. Second, many educational policy makers still depend on the concept of functional literacy. For example, the functional concept of literacy only provides the skills needed to strengthen the competitiveness of the national economy [24]. Third, literacy is only implemented in schools, it should be to create more inclusive literacy practices, we must understand the relationship of literacy practices with discourse, family, and community environment [25]. Fourth, students still experience difficulty in reading [26][27]. Difficulties such as recognizing words, understanding what is read, lack of fluency in reading, recognition and flexibility with the use of reading strategies to overcome a variety of diverse and complex texts [28].

Literacy reading and writing in language learning activities aim to improve students' knowledge and skills. However, in the Indonesian school curriculum, aspects that students need to have after learning are to increase knowledge, skills, and shape student character through character education that is integrated in the learning process. Schools as educational institutions are one important source for building student character [29]. The idea of a school as instilling virtue is as old as the school itself [30]. Character is an important manifestation of the implementation of the education process at every level of education from basic education to higher education [31][32][33]. In other words, educational policy must lead to the realization of moral education in the school system [30].

Character education must explicitly appear in learning and at the same time become the soul and learning objectives [34]. The teacher must find a way to instill curriculum with character building [35]. Formation of character and academic ability in a learning process can be done if a teacher is able to choose and use the right learning model [36]. The use of learning models as a means of character education seems more effective and tends to approach the actual concept of character education [37]. Based on these explanations, a Model of Genre Based Learning was developed by integrating literacy activities and character strengthening in language learning. The purpose of this study was to develop a genre based learning model design that integrated literacy activities and character strengthening for junior high school students. 


\section{Method}

Type of research is research and development. The learning model development process is carried out following the Plomp model (preminary research, prototyping phase, and assessment phase) [38]. This paper reports on the results of the prototyping phase in the form of syntax based genre learning models integrated in literacy activities and character strengthening for middle school students. The model that has been designed is then validated by the researchers themselves and experts with the help of research instruments in the form of a questionnaire.

\section{Result and Disscussion}

In Indonesia, Language learning in the latest curriculum, Curriculum 2013, Genre based learning is one approach that can be used in the learning process, known as the text-based curriculum. Followed by a new curriculum, in 2013, the School Literacy Movement was launched which aims to increase student literacy, and strengthen character education to shape moral students. After the activity is carried out, there are several obstacles, one of which is the implementation of the school literacy movement and the strengthening of character is only carried out by certain teachers and in the language learning process is not implemented optimally. Therefore, one of the solutions is to develop a Genre based learning model by integrating literacy activities and character strengthening. The syntax of the developed learning model can be seen in table 1 .

Table 1. Design of genre based learning models integrated in literacy activities and character strengthening for middle school students

\begin{tabular}{|c|c|c|}
\hline Syntax & Activity & $\begin{array}{l}\text { Character } \\
\text { strengthening }\end{array}$ \\
\hline Build context & $\begin{array}{l}\text { The teacher introduces the text to students and asks } \\
\text { them to pay attention to the possible socio-cultural } \\
\text { conditions in which the text is produced. }\end{array}$ & $\begin{array}{l}\text { independent, } \\
\text { critical }\end{array}$ \\
\hline Explore genres & $\begin{array}{l}\text { Students find examples of texts that are related to } \\
\text { the same genre of text as the texts that have been } \\
\text { read and analyzed in various print and electronic } \\
\text { media sources. }\end{array}$ & $\begin{array}{l}\text { honest, creative, } \\
\text { independent }\end{array}$ \\
\hline Building & Students choose topics and hearings to gather & critical, \\
\hline knowledge & $\begin{array}{l}\text { insights they can use when writing. Next, students } \\
\text { choose one text to read and analyze to report. }\end{array}$ & $\begin{array}{l}\text { disciplined, } \\
\text { responsible }\end{array}$ \\
\hline Report reading & $\begin{array}{l}\text { Students report reading as much as one or more } \\
\text { texts read. The report contains the text's identity, } \\
\text { text summary, comments on the contents of the text, } \\
\text { and evaluation. }\end{array}$ & $\begin{array}{l}\text { honest, } \\
\text { disciplined, } \\
\text { responsible }\end{array}$ \\
\hline Analyzing genre & $\begin{array}{l}\text { Students read one of the texts that have been found } \\
\text { and analyze the structure of the text and the } \\
\text { language characteristics of the text that has been } \\
\text { read. }\end{array}$ & $\begin{array}{l}\text { honest, } \\
\text { disciplined, } \\
\text { responsible }\end{array}$ \\
\hline $\begin{array}{l}\text { Constructing } \\
\text { individual texts } \\
\text { and/orgroups }\end{array}$ & $\begin{array}{l}\text { Students write text based on the steps of writing. } \\
\text { These activities can be carried out individually } \\
\text { and/or in groups. Writing steps are based on the }\end{array}$ & $\begin{array}{l}\text { honest, } \\
\text { disciplined, } \\
\text { responsible, }\end{array}$ \\
\hline
\end{tabular}




\begin{tabular}{ll} 
Evaluation, & $\begin{array}{l}\text { genre being studied. } \\
\text { Students answer questions and provide opinions and caring, brave, } \\
\text { presentation and } \\
\text { reflection }\end{array}$ \\
& $\begin{array}{l}\text { suggestions regarding learning that has been done. honest } \\
\text { Next, students present the written text and discuss } \\
\text { what is the problem and what makes it easier for } \\
\text { students in the learning process. }\end{array}$ \\
\hline
\end{tabular}

The learning model that has been developed is then validated. Validation is done in two ways, namely self evaluation and expert validation. The results of the validation of the learning model developed can be seen in table 2 and table 3.

Table 2. Self evaluation

\begin{tabular}{lcl}
\hline Rated aspect & Score & Category \\
\hline Content & 87.50 & Very valid \\
Language & 91.67 & Very valid \\
Validity results & 89.58 & Very valid \\
\hline
\end{tabular}

Table 3. Expert validation

\begin{tabular}{lll}
\hline Rated aspect & Score & Category \\
\hline Content & 88.55 & Very valid \\
Language & 93.75 & Very valid \\
Validity results & 91.15 & Very valid \\
\hline
\end{tabular}

The learning model developed is categorized as very valid, so it can be continued to be tested in schools. Trials are conducted to obtain the practicality and effectiveness of the learning model.

Genre based learning emphasizes giving genre knowledge to students at the textual level. However, students are made passively and less attention is given to students' needs for basic writing skills and requirements for their language accuracy [39]. This model for teaching writing is presented as a challenging model for use in the classroom because "it refers to a pedagogy that involves examining and deconstructing examples of genre (text categories) [40]. At the same time, students follow several stages, namely: deconstruction, joint construction, and individual construction[8], when dealing with the process of writing to negotiate meaning through writing [41].

To apply the Genre Based Learning approach to the teaching process for reading and writing skills, the teaching and learning cycle includes three phases of instruction, deconstruction, joint construction, and individual construction [42]. The new model of genrebased teaching which was previously described as having three phases added one stage namely building field knowledge, to foster students' knowledge about the main features of social circumstances and relate them to genre content [43]. By considering the weaknesses of the three-phase Genre Based Learning, the model was developed by adding two stages, namely building context and reflection at the beginning and end of the learning step for learning to write argumentative texts [10].

Some experts also developed a Genre based learning model consisting of three cycles by adding one learning phase. This model methodologically involves four important stages, 
namely building the context of field, modeling the text, guided practice, and indenpendent construction [6][7][9]. Unlike the previous explanation, the standard of Genre Based Learning activities in learning to write is done in six steps. These steps include exploring genres, building knowledge of field, exploring the genre, joint text construction, building knowledge of a similar field, drafting, revising \& conferencing, and editing \& publishing [18][44]. Based on the explanation by several previous researchers, this model was developed to be applied to the language learning process by integrating literacy activities and character strengthening based on school curriculum policies.

\section{Conclusions and Suggestions}

Based on the results of the study and discussion it was concluded that it was important to develop a learning model that integrated literacy activities and character strengthening. The learning model is used for language learning to read and write texts. The learning model developed is categorized as very valid and can then be tested in school to find out the practicality and effectiveness of the developed model. It is recommended for further researchers to be able to develop other aspects that support to increase literacy and strengthen student character by developing other aspects in the language learning process. This learning model can be used by teachers for language learning in learning all texts and can be adapted to the genre being studied.

\section{Acknowledgements}

A sincere thanks goes to the expert validator involved in validating the product being designed. The researchers also thanked the Directorate General of Higher Education for providing research grants.

\section{References}

[1] K. Hyland, "Genre pedagogy: Language, literacy and L2 writing instruction," $J$. Second Lang. Writ., vol. 16, no. 3, pp. 56-64, 2007.

[2] J. R. Martin, "Embedded literacy: Knowledge as meaning," Linguist. Educ., vol. 24, no. 1, pp. 23-37, 2013.

[3] Y. Wu and H. Dong, "Applying SF-based genre approaches to english writing class," Int. Educ. Stud., vol. 2, no. 3, pp. 77-81, 2009.

[4] G. Myskow and K. Gordon, "A focus on purpose : using a genre approach in an E L writing class," ELT J., vol. 64, no. 3, pp. 283-292, 2010.

[5] T. Ueasiriphan and S. Tangkiengsirisin, "The effects of genre- based teaching on enhancement of Thai engineers ' technical writing ability," Int. J. Instr., vol. 12, no. 2, pp. 723-738, 2019.

[6] B. Derewianka, "Trends and issues in genre-based approaches," RELC J., vol. 34, no. 2, pp. 133-154, 2017.

[7] J. Richard, Communicative language teaching today. Cambridge, UK: Cambridge University Press, 2006.

[8] D. Rose and J. R. Martin, Learning to write, reading to learn: Genre, knowledge and pedagogy in the Sydney school. Sheffield, UK: Equinox, 2012.

[9] I. W. Dirgeyasa, "Genre-based approach: What and how to teach and to learn writing," English Lang. Teach., vol. 9, no. 9, pp. 45-51, 2016.

[10] Y. Sawangsamutchai and S. Rattanavich, “). A Comparison of seventh grade thai students' reading comprehension and motivation to read english through applied 
instruction based on the genre-based approach and the teacher's manual.," English Lang. Teach., vol. 9, no. 4, pp. 54-63, 2016.

[11] Y. Yang, "Teaching Chinese college esl writing: a genre-based approach," English Lang. Teach., vol. 9, no. 9, pp. 36-44, 2016.

[12] R. Badger and G. White, "A process genre approach to teaching writing," ELT J., vol. 54, no. 2, pp. 153-160, 2000.

[13] P. D. La Cerda, "The design of a theme-based and genre-oriented strategic reading course to improve students' reading comprehension skills at a public school in Colombia.," HOW, vol. 23, no. 1, pp. 49-67, 2016.

[14] Kemendikbud, Konsep dan Implementasi Kurikulum 2013. Jakarta: Kemendikbud, 2014.

[15] B. Sadeghi, M. T. Hassani, and M. R. Hemmati, "The effects of genre-based instruction on ESP learners " reading comprehension," Theory Pract. Lang. Stud., vol. 3, no. 6, pp. 1009-1020, 2013.

[16] N. N. Kalali, "Genre analysis and writing skill: Improving Iranian EFL learners writing performance through the tenets of genre analysis," Adv. Lang. Lit. Stud., vol. 6, no. 6, pp. 119-130, 2015.

[17] J. S. Early and M. Decosta-smith, "Making a case for college: A genre-based college admission essay intervention for underserved high school students," J. Writ. Res., vol. 2, no. 3, pp. 299-329, 2015.

[18] P. A. C. Bejarano and C. M. Chapetón, "The role of genre-based activities in the writing of argumentative essays in EFL," Profile, vol. 15, no. 2, pp. 127-147, 2013.

[19] J. A. Swami, "Sensitizing ESL learners to genre," Teach. English as a Second or Foreign Lang., vol. 12, no. 3, pp. 1-13, 2008.

[20] I. Lee, "Genre-based teaching and assessment in secondary English classrooms," English Teach. Pract. Crit., vol. 11, no. 4, pp. 120-136, 2012.

[21] A. Nagao, "A genre-based approach to writing instruction in EFL classroom contexts," English Lang. Teach., vol. 11, no. 5, pp. 130-147, 2018.

[22] L. F. Gómez-rodríguez, "Implementing critical thinking tasks to fostering english learners' intercultural communicative competence in a genre-based learning environment.," English Lang. Teach., vol. 11, no. 12, pp. 154-165, 2018.

[23] V. Indriyani, M. Zaim, Atmazaki, and S. Ramadhan, "Literasi baca tulis dan inovasi kurikulum bahasa," Kembara, vol. 5, no. 1, pp. 108-118, 2019.

[24] L. Pinto, M. Boler, and T. Norris, "Literacy is Just Reading and Writing, Isn ' t It? The Ontario Secondary School Literacy Test and Its Press Coverage," Policy Futur. Educ., vol. 5, no. 1, pp. 84-99, 2007.

[25] T. Rogers, C. Tyson, and E. Marshall, "Living dialogues in one neighborhood: Moving toward understanding axrooss discourses and practices of literacy and schooling.," J. Lit. Res., vol. 32, no. 1, pp. 1-24, 2000.

[26] M. Suryaman, "Analisis hasil belajar peserta didik dalam literasi membaca melalui studi internasional (PIRLS) 2011," Litera, vol. 14, no. 1, pp. 170-186, 2011.

[27] K. K. Frankel, "The intersection of reading and identity in high school literacy intervention classes," Res. Teach. English, vol. 51, no. 1, pp. 37-59, 2016.

[28] B. G and S. C, Reading text: a vision of action and research in middle and high school literacy. Washinton DC: Alliance for Excellent Education.

[29] S. A. Kamaruddin, "Character education and students social behavior," J. Educ. Learn., vol. 6, no. 4, pp. 223-230, 2012.

[30] T. Lickona and T. Roosevelt, "The return of character education," Educ. Leadersh., 
vol. 5, pp. 6-11, 1993.

[31] G. D. Kuh and P. D. Umbach, "College and character: insights from the national survey of student engagement," New Dir. Institutional Res., no. 122, pp. 37-55, 2004.

[32] A. Hidayati, M. Zaim, K. Rukun, and Darmansyah, "The development of character education curriculum for elementary student in West Sumatera," Int. J. Educ. Res., vol. 2, no. 6, pp. 189-198, 2014.

[33] W. S. Mak, "Evaluation of a moral and character education group for primary school students.," Discov. - SS Student E-journal, vol. 3, pp. 142-164, 2014.

[34] B. Novick, J. Kress, and M. Elias, Building learning comunities with character. Alexandria: ASCD, 2002.

[35] S. L. McEmeel, Character education: A book guide of teachers, librarians, and parents. Greenwood Village, CO: Teacher Ideas Press, 2002.

[36] T. Lickona, Character matter. New York: A Touchtone Book, 2004.

[37] Y. Abidin, "Model penilaian otentik dalam pembelajaran membaca pemahaman berorientasi pendidikan karakter," J. Pendidik. Karakter, vol. 2, no. 2, pp. 164-178, 2012.

[38] T. Plomp, Educational design research: an intruction. enschede: slo: netherlands institute for curiculum development, 2013.

[39] Y. Zhang, "Exploring EFL learners' self-efficacy in academic writing based on process-genre approach," English Lang. Teach., vol. 11, no. 6, pp. 115-124, 2018.

[40] I. Bruce, Academic writing and genre: A systematic analysis. New York: Continuum, 2008.

[41] E. G. Burgos, "Use of the genre-based approach to teach expository essays to English pedagogy students," HOW, vol. 24, no. 2, pp. 141-159, 2017.

[42] J. Rothery, "Making changes: Developing an educational linguistics," in Literacy in society, R. Hasan and G. Williams, Eds. London: Longman, 1996, pp. 86-123.

[43] S. Hyon, "Genre in three traditions: Implications for ESL," TESOL Q., vol. 30, no. 4, p. $693-722,1996$.

[44] H. P. Widodo, "Designing a genre-based lesson plan for an academic writing course," English Teach. Pract. Crit., vol. 5, no. 3, pp. 173-199, 2006. 